\title{
Biological nitrate removal from water resources
}

\author{
${ }^{*}$ G. R. Nabi Bidhendi, T. Nasrabadi, H. R. Sharif Vaghefi and H. Hoveidi \\ Department of Environment Engineering, University of Tehran, Tehran, Iran
}

Received 3 January 2006; revised 10 May 2006; accepted 21 May 2006; available online 25 June 2006

\begin{abstract}
During the recent decades, the increasing trends in nitrate ion concentration in ground water sources have meant more research to find effective procedures for the prevention of even more water contamination by nitrogen sources. In this study a pilot was designed to examine the application of biological method for eliminating nitrate from the water of well No.903 of Mehrabad Airport, Tehran, Iran. Design, installation and running processes were done from April to November 2003. A fixed biological bed containing five-centimeter trunk pipes $16 \mathrm{~mm}$ in diameter were installed in the reactor and the system was operated with upflow current. Instead of Methanol, Acetic acid was used as the carbon source because of its easier acceptance by the public, lower price and availability as well as easier storage. The pilot was run in different hydraulic retention times from $48 \mathrm{~h}$ up to one hour. Considering economical, operational and maintenance factors, retention time of $2 \mathrm{~h}$ was determined to be optimum, in which $77 \%$ nitrate removal was achieved. Considering a ratio of 2 for COD/N, inlet COD of about $140 \mathrm{mg} / \mathrm{L}$ and the optimum retention time, COD removal of about $80 \%$ is also accomplished in this process. The amount of nitrite concentration, $\mathrm{pH}$ values, COD and turbidity is also evaluated versus different hydraulic retention times.
\end{abstract}

Keywords: Biological reactor, biological nitrate removal, water resources

\section{INTRODUCTION}

A continuous withdrawal of water from underground sources in large quantities, the increasing levels of sewage water percolating in to the underground sources in Tehran area as well as the random application of nitrate fertilizer in farms have led to increases in nitrate concentration of underground sources in recent decades (Thanth and simard, 1973 and Senju et al., 1989). Therefore it is necessary to use various methods of removing nitrate as well as to apply effective means of preventing further pollution. Among various methods, biological elimination method for purification of water is considered to be justifiable for economical reasons as well as for being a clean source in terms of secondary pollutions. This research includes a pilot project using biological reactor for removing nitrate from Mehrabad Airport as a case study.

\section{MATERIALS AND METHODS}

A reactor was made of Plexiglas for the purpose of pilot project. The cross section of the reactor and the height measured at $30 \mathrm{~cm} \times 30 \mathrm{~cm}$ and $90 \mathrm{~cm}$ respectively, giving an operational volume of $81 \mathrm{~L}$. One $\frac{1}{2}$ inlet valve,

*Corresponding author, Email: ghhendi@ut.ac.ir

Tel.: +9821-6640 7719; Fax: +9821-6640 4647 one $1 / 2$ sludge removal valve and three other $1 / 2$ valves were installed at a height of $5 \mathrm{~cm}$, at the bottom of the reactor tank and at 45,65 and $85 \mathrm{~cm}$ from the inlet valve, respectively. The system was equipped with two raw water sources with a dosing pump that was used, to regulate the rate of water delivery; and a second pump that injected acetic acid at predetermined rates. The specifications of the dosing pumps are as follows:

The raw water dosing pump was used with a pumping capacity of $220 \mathrm{~L}$ per hour at a pressure of 10 bars, along with a mixing set, an electrical board, and two 500-liter tanks with connecting valves and pipes installed on a chassis. The acid injecting dosing pump is made with a pumping capacity of five liters per hour at a pressure of 10 bars, and is equipped with a filter. A mixing set was used to add acid to the raw water. The set was operated with a board at the reactor location. The reactor and the appurtenances were roomed in a $5 \times 3 \mathrm{~m}$ construction to control air temperature. The raw water was drawn from well 903 which supplied to the reservoir No. 15 at Mehrabad airport. The specifications of the well are given in Tables 1 and 2. Finally a ${ }^{1 / 2}$ galvanized pipe was used to deliver water from this well to the reservoir. 
Table 1: Experimented well characteristics

\begin{tabular}{ccccc}
\hline Year constructed & Well depth $(\mathrm{m})$ & $\begin{array}{l}\text { Depth of pump } \\
\text { installation }(\mathrm{m})\end{array}$ & Water table depth (m) & $\begin{array}{c}\text { Allowable flow } \\
\text { lit/sec }\end{array}$ \\
\hline 1990 & 168 & 126 & 73 & $300-150$ \\
\hline
\end{tabular}

Table 2: Chemical analysis of experimented well water

\begin{tabular}{ccccccc}
\hline Date tested & $\begin{array}{c}\text { Electrical conductivity } \\
(\mu \mathrm{s} / \mathrm{cm})\end{array}$ & $\begin{array}{c}\text { Turbidity } \\
(\mathrm{FTU})\end{array}$ & $\begin{array}{c}\text { Sulfate } \\
(\mathrm{mg} / \mathrm{L})\end{array}$ & $\mathrm{pH}$ & $\begin{array}{c}\text { Nitrite } \\
(\mathrm{mg} / \mathrm{L})\end{array}$ & $\begin{array}{c}\text { Nitrate } \\
(\mathrm{mg} / \mathrm{L})\end{array}$ \\
\hline April 1990 & 575 & 54 & 42 & 7.5 & 0.001 & 15 \\
Feb. 1998 & 702 & 1 & 130 & 7.5 & 0.01 & 17 \\
Nov. 1999 & 719 & 1 & 88 & 7.5 & 0.03 & 79.5 \\
April 2001 & 680 & 0.1 & 62 & 7.5 & 0.02 & 78.2 \\
\hline
\end{tabular}

Three hollowed sheets with with average hole diameter of one centimeter were used in the reactor for the following purposes:

A: One sheet directly above the inlet pipe to regulate the flow into the biological reactor.

$\mathrm{B}$ : One sheet at the end of the second outlet pipe above the reactor to stabilize the pressure in the reactor bed. $\mathrm{C}$ : A third sheet above the reactor to allow $\mathrm{N}_{2}$ and $\mathrm{CO}_{2}$ gases to escape.

Fig. 1 shows a schematic drawing of the nitrate removal pilot system from well No. 903. A biological method with a fixed bed was used in this pilot project to remove nitrates from the well water. An up-flow current was used in the reactor because of favorable results obtained with an up-flow current with fixed biofilm domestically as well as in other countries (Torabian et al., 1998; Imandel and Iranshahi, 1995; Torabian et al., 2002 and Mesdaghinia and Shariat, 1998). Five centimeter trunk pipes $16 \mathrm{~mm}$ in diameter were installed in the reactor to function as the biological bed. Raw water was delivered to the storage tanks through a $1 / 2$ pipe. Industrial grade acetic acid was used as a carbon source for the heterotrophic bacteria in the biological reactor. The water contained enough phosphorus for these organisms to survive. Acetic acid was injected into these storage tanks from which water was supplied to the reactor. The raw water was sampled on a monthly basis for chemical analysis. Nitrate concentrations varied from 72 to $79 \mathrm{mg} / \mathrm{L}$ and assumed approximately $75 \mathrm{mg} / \mathrm{L}$ for practical purposes. The required rates of acetic acid were based on the concentrations of dissolved oxygen and nitrate in the incoming water according to the stoichiometric values obtained by researchers at Colorado State University (Bouchard et al.,1992 and Degremont, 1991).

$$
\begin{aligned}
& \mathrm{NO}_{3}^{-}+0.88 \mathrm{CH}_{3} \mathrm{COO}^{-}+\mathrm{H}^{+} \longrightarrow 0.09 \mathrm{C}_{5} \mathrm{H}_{7} \mathrm{NO}_{2}+0.46 \mathrm{~N}_{2}+0.42 \\
& \mathrm{CO}_{2}+0.88 \mathrm{HCO}_{3}^{-+}+1.7 \mathrm{H}_{2} \mathrm{O} \\
& \mathrm{O}_{2}^{-}+1.43 \mathrm{CH}_{3} \mathrm{COO}^{-}+0.26 \mathrm{NO}_{3}^{-}+0.26 \mathrm{H}^{+} \longrightarrow 0.27 \\
& \mathrm{C}_{5} \mathrm{H}_{7} \mathrm{NO}_{2}+0.1 \mathrm{CO}_{2}+1.43 \mathrm{HCO}_{3}^{-}+0.63 \mathrm{H}_{2} \mathrm{O}
\end{aligned}
$$

These equations indicated that $65 \%$ of the acetic acid is used up for dissolved oxygen as electron acceptors in cell production. The remaining 35\% is used for thenitrogen atoms as electron acceptors. Due to operational problems in the system with regard to regulating the rate of acetic acid injection a second acid dosing pump was installed in the acid delivery system. Acetic acid was injected at the head of the inlet pipe. As a result the well water was delivered in to the flow regulating water source and from there in to the reactor by a dosing pump. Making sure of a stable microbial biomass on the reactor bed after four weeks of operation, the acetic acid flow was regulated so as to have a hydraulic retention time of 48 h Hydraulic retention time here is defined as the time it takes for raw water to move from the inlet to the exit valve. After the system was stabilized, hydraulic retention time was also reduced. So that this reduced retention time was measured at $1.5 \mathrm{~h}$ whereby the system efficiency was the lowest and the effluent solution constrained the lowest concentration of nitrite. During the working course the hydraulic retention time was reduced from 48 to 24 , to 12 , to 6 , to 3 to 2 , to 1.5 and finally to $1 \mathrm{~h}$ periods. The concentrations of nitrate, nitrite, $\mathrm{pH}, \mathrm{COD}$, turbidity and the temperature of treated water samples collected at the exit valves were measured for each cycle of retention times, using HACH DR 2000, DR 4000, pHmeter from the faculty of environmental sciences and laboratory of Tehran province. The above-mentioned parameters were determined according to the standard method manual (De Zuane, 1990; WHO, 1996; Hammer, 1986; Chapman, 1997; Master, 1991 and AWWA, 1998). 


\section{Operational problems}

The following are some of the operational problems, which are normal for the pilot projects that need construction, start-up, maintenance and operations:

A major obstacle was to find materials for the system components to be acid resistant and non-corrosive when they are in contact with the acetic acid that used as a nutrient source. Due to the need for controlling and regulating the various functions of the system with a single board; it were faced with design and construction problems including the design of a warning system for electrical cutoff, an automatic electrical connection and disconnection function, the mixer and the dosing pump controls. With regard to the water storage reservoir activation as a secondary reactor, and towards prevention of any fault in the system, changes needed to be made in Acid injection pilot, by using a suitable dosing pump set. This way the pilot carry out a more precise injection of acetic acid into the system at such an operational level. Due to the fact that the nitrate- removing bacteria have a slow growth rate inside the reactor attempts were made to grow them in a 2 liter beaker containing a solution culture cosseting of $\mathrm{KNO}_{3}$ at $790 \mathrm{mg} \mathrm{NO} / \mathrm{l}$ and $\mathrm{CH}_{3} \mathrm{COOH}$ homogenized by an electric mixer. The concentration of nitrate decreased to $5 \mathrm{mg} / \mathrm{L}$ in $48 \mathrm{~h}$ The bacteria were then added to the reactor for further growth and nitrate reduction. The operational parameters varied at the start-up and during the regular functioning. For example acidic shock affected the biological processes when $\mathrm{pH}$ fell below 5 making it necessary to have to wash up and restart the system. Limitations imposed by the construction and use of various biological beds for the system. As can be seen from Table 3 the nitrate concentration at exit valve no. 1 varied from 10.4 to $25.1 \mathrm{mg} / \mathrm{L}$. These amounts correlate to nitrate removal rates from $66.5 \%$ to $86.1 \%$. As can be seen from Table 4, the minimum nitrate concentration for a hydraulic retention time of $48 \mathrm{~h}$ was measured at $8.4 \mathrm{mg} / \mathrm{L}$ meaning $88.8 \%$ removal, and a maximum of $20.3 \mathrm{mg} / \mathrm{L}$ equaling $72.9 \%$ removal (Fig. 2).

Table 3: Nitrite and COD removal in the reactor at well No. 903 (exit valve or No.1)

\begin{tabular}{|c|c|c|c|c|c|c|}
\hline $\begin{array}{l}\text { Turbidity } \\
\text { (FTU) }\end{array}$ & $\begin{array}{c}\text { Average } \\
\mathrm{pH}\end{array}$ & $\begin{array}{c}\text { COD removal } \\
\%\end{array}$ & $\begin{array}{l}\text { Average rutlet } \\
\text { COD (mg/L) }\end{array}$ & $\begin{array}{c}\text { Average exit } \\
\text { nitrite } \\
(\mathrm{mg} / \mathrm{L})\end{array}$ & $\begin{array}{c}\text { Nitrate } \\
\text { removal } \\
\%\end{array}$ & $\begin{array}{c}\text { Average exit } \\
\text { nitrate } \\
(\mathrm{mg} / \mathrm{L})\end{array}$ \\
\hline 20.8 & 6.4 & 68.6 & 44 & 16.8 & 66.5 & 25.1 \\
\hline 16.5 & 6.5 & 74.1 & 36.3 & 4.2 & 70.9 & 21.8 \\
\hline 10.6 & 6.7 & 78.3 & 30.4 & 0.075 & 69.1 & 20.2 \\
\hline 11.1 & 6.7 & 77.8 & 31.1 & 0.01 & 73.7 & 19.7 \\
\hline 9.9 & 6.6 & 79.1 & 29.3 & 0.05 & 75.5 & 18.4 \\
\hline 6.9 & 6.8 & 81.5 & 25.9 & 0.05 & 76.1 & 17.9 \\
\hline 4.8 & 6.8 & 83.1 & 23.7 & 0.025 & 81.6 & 13.8 \\
\hline 4.8 & 7 & 83.5 & 23.1 & 0.03 & 83.6 & 12.3 \\
\hline 4.4 & 7 & 86.7 & 18.6 & 0.01 & 83.3 & 12.5 \\
\hline 4.2 & 7.4 & 87.6 & 17.3 & 0.001 & 83.9 & 12.1 \\
\hline 4 & 7.5 & 88.5 & 16.1 & 0.001 & 86.1 & 10.4 \\
\hline
\end{tabular}

Table 4: Nitrate, nitrite and COD removal in the reactor at well No. 903 (finish valve or No. 2)

\begin{tabular}{|c|c|c|c|c|c|c|c|}
\hline $\begin{array}{l}\text { Turbidity } \\
\text { (FTU) }\end{array}$ & $\begin{array}{c}\text { Average } \\
\text { PH }\end{array}$ & $\begin{array}{c}\text { COD } \\
\text { removal } \\
\%\end{array}$ & $\begin{array}{c}\text { Average } \\
\text { outlet } \\
\text { COD }(\mathrm{mg} / \mathrm{L})\end{array}$ & $\begin{array}{c}\text { Average exit } \\
\text { nitrite } \\
(\mathrm{mg} / \mathrm{L})\end{array}$ & $\begin{array}{c}\text { Nitrate removal } \\
\%\end{array}$ & $\begin{array}{c}\text { Average exit } \\
\text { nitrate } \\
(\mathrm{mg} / \mathrm{L})\end{array}$ & $\begin{array}{c}\text { Retention } \\
\text { time (h) }\end{array}$ \\
\hline 20.4 & 6.9 & 74.4 & 35.8 & 16.4 & 72.9 & 20.3 & 1 \\
\hline 16 & 7 & 79.2 & 29.1 & 4 & 76.5 & 17.6 & 1.5 \\
\hline 8 & 7 & 82.6 & 24.4 & 0.06 & 78.9 & 15.8 & 2 \\
\hline 10 & 7 & 82 & 25.1 & 0.09 & 78.8 & 15.9 & 2.5 \\
\hline 4.4 & 7 & 86.4 & 19.1 & 0.02 & 85.3 & 11 & 5 \\
\hline 4.6 & 7.2 & 86.7 & 18.4 & 0.03 & 86.8 & 9.9 & 6 \\
\hline 4.1 & 7.4 & 89.3 & 15 & 0.001 & 86.5 & 10.1 & 12 \\
\hline 3.9 & 7.5 & 90 & 13.9 & 0.001 & 87.2 & 9.6 & 24 \\
\hline 3.8 & 7.7 & 90.7 & 13 & 0.001 & 88.8 & 8.4 & 48 \\
\hline
\end{tabular}




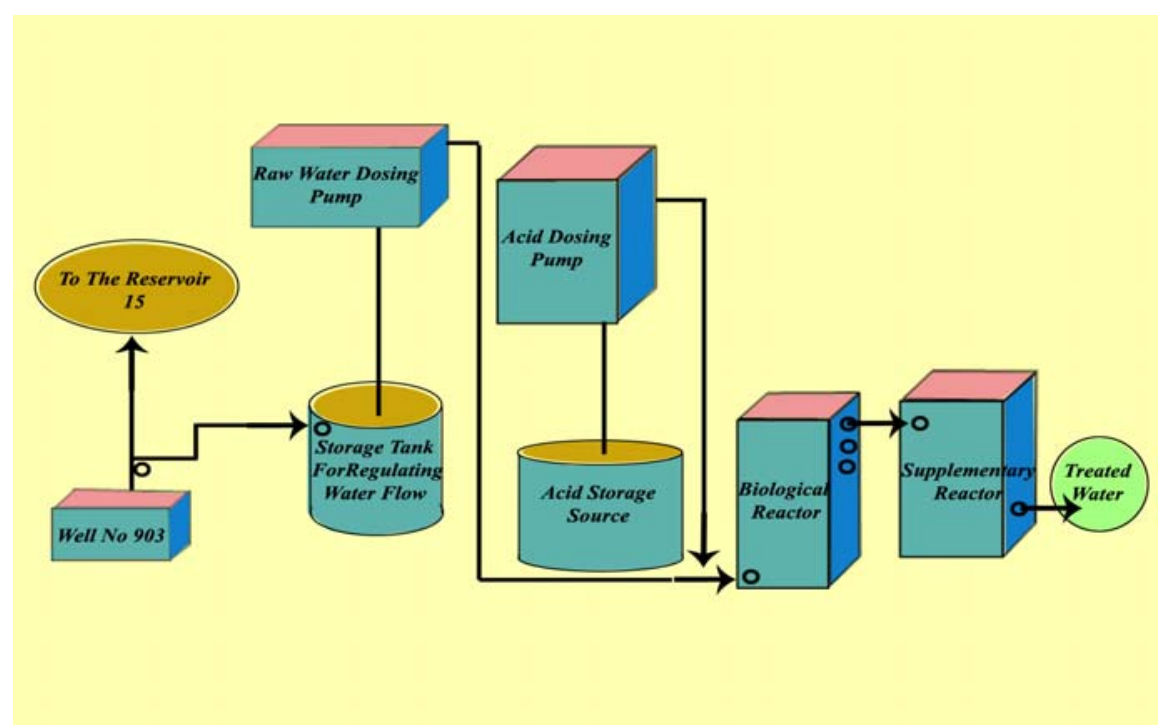

Fig. 1: Schematic representation of nitrate removing pilot plant for well No 903

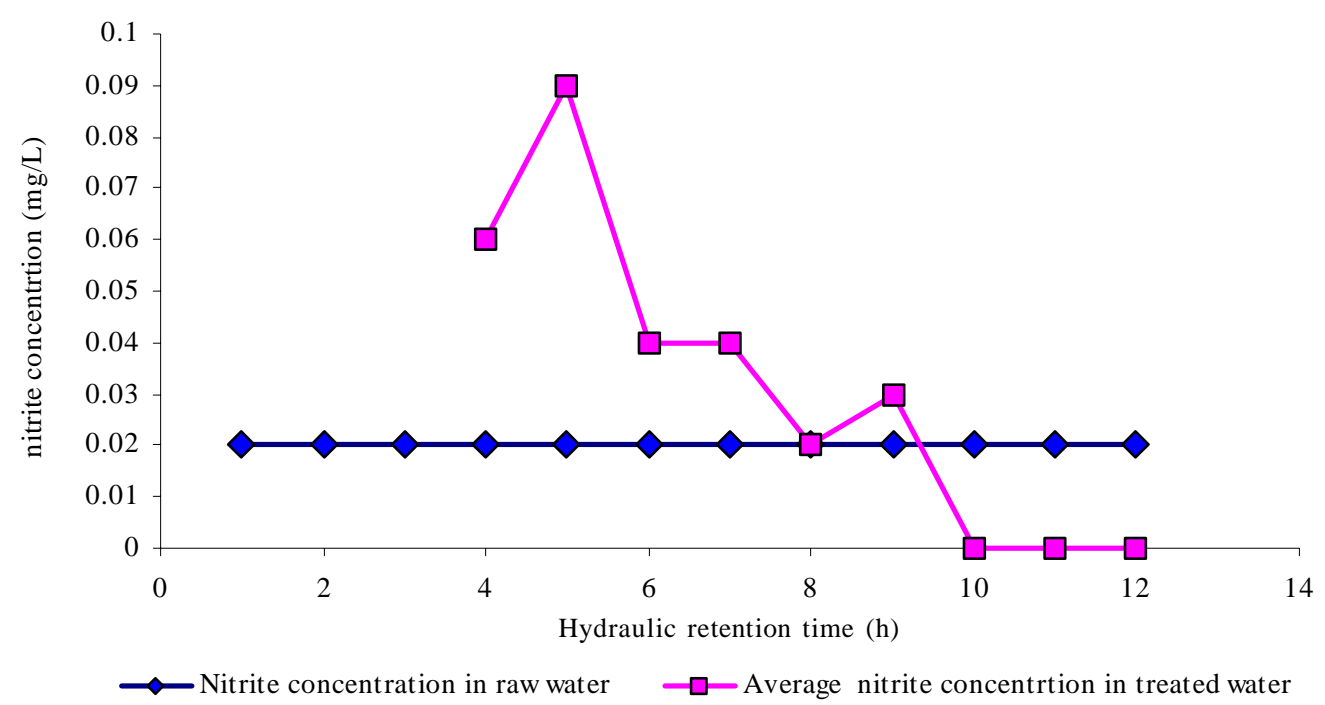

Fig. 2: Nitrate concentration versus reactor hydraulic retention time in water of well No. 903

\section{Effect of retention time on COD levels}

A comparison between the variations in COD levels of treated water as affected by the hydraulic retention time clearly indicated that this parameter is more sensitive to the time of retention than is nitrate. As can be seen from Table 3 the minimum COD removal measured at valve no 1 was $68.6 \%$ with an average concentration of $44 \mathrm{mg} /$ $\mathrm{L}$ and a maximum removal of $88.5 \%$ with a COD of 16.1 $\mathrm{mg} / \mathrm{L}$. However, the following were observed at valve no. 2. COD removal maximized at $90.7 \%$ with a concentration of $13 \mathrm{mg} / \mathrm{L}$ and minimized at $74.4 \%$ with a COD level of $35.8 \mathrm{mg} / \mathrm{L}$. The effects of hydraulic retention time on COD concentrations measured at two valves are shown in Fig. 3.

\section{Effect of retention time on water $\mathrm{pH}$}

The rate of nitrate removal decreases for $\mathrm{pH}$ values less than six or higher than eight. The highest rate is measured between $\mathrm{pH} 7.0$ and 7.5. Considering that the $\mathrm{pH}$ of the raw water was 7.5 and combining this with the effect of acetic acid on the pH during the treatment of water for various retention times, $\mathrm{pH}$ values were calculated and presented in Tables 3 and 4 . It can be seen from Fig. 4 that there were small $\mathrm{pH}$ variations observed at the finish valve. 


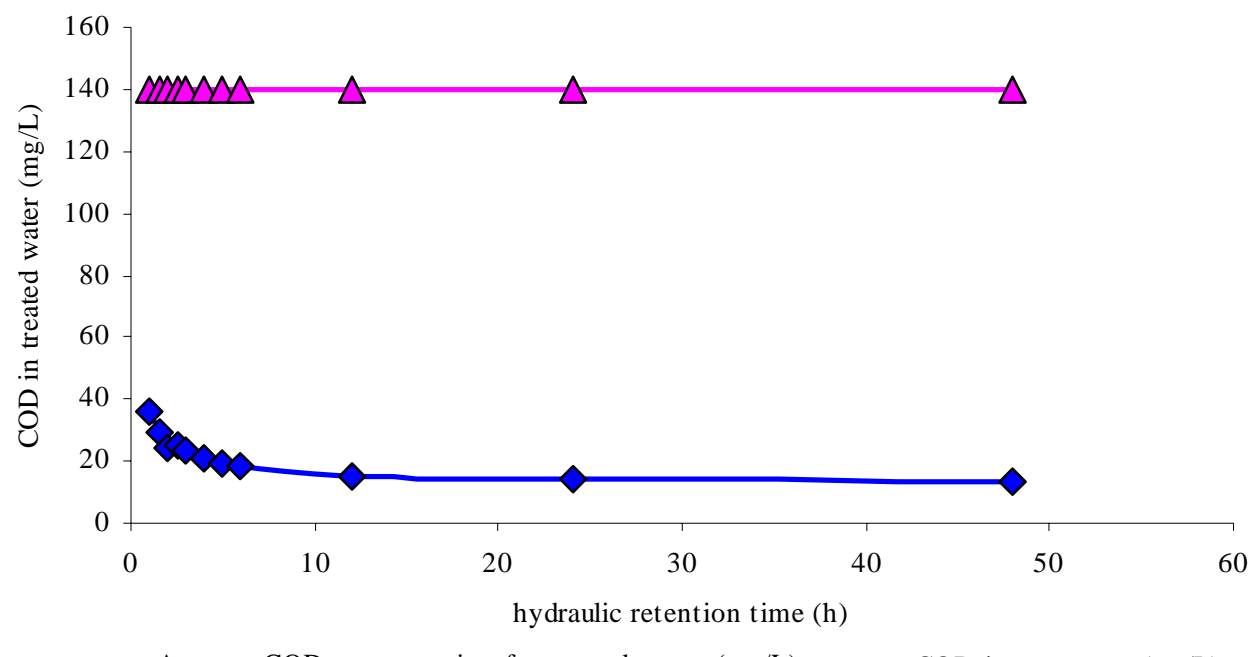

Fig. 3: COD concentration versus reactor hydraulic retention time in water of well No. 903

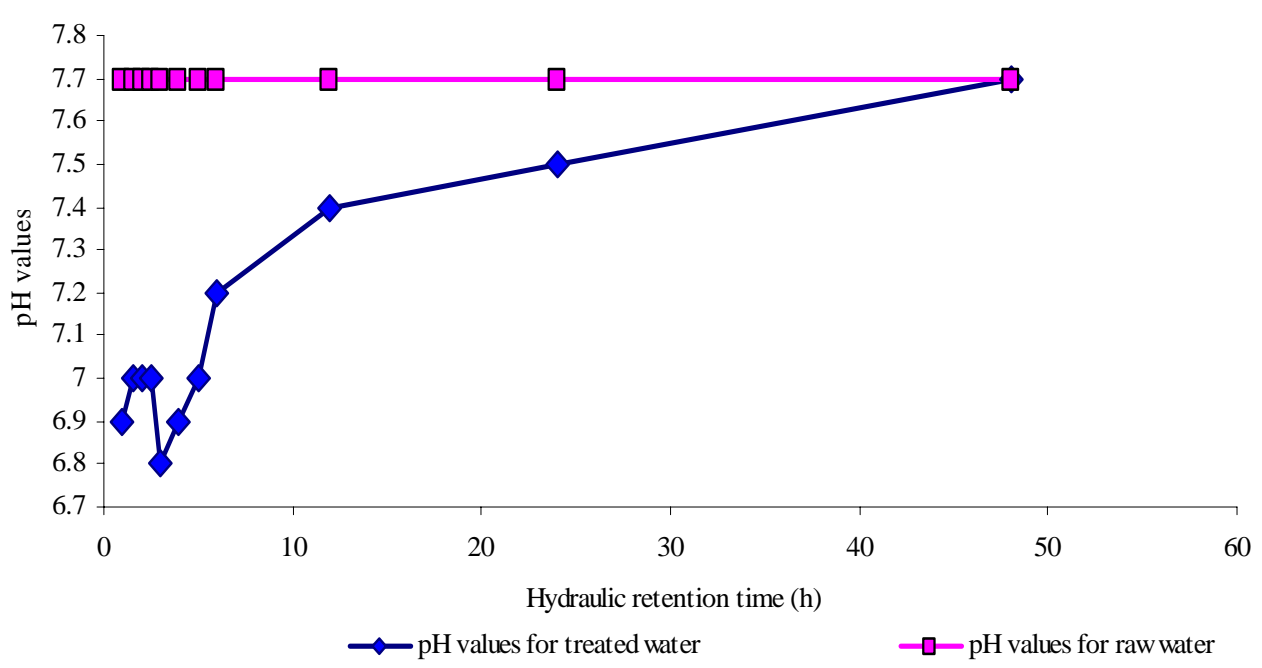

Fig. 4: $\mathrm{pH}$ variations of water versus retention time

Effect of retention time on nitrite concentrations

The concentration of nitrite (intermediate ion) in raw water increased considerably as the retention time was decreased to $1.5 \mathrm{~h}$ As can be seen from Table 4 the concentration of this intermediate ion did not exceed a few hundredth of a mg per liter for retention times longer than $1.5 \mathrm{~h}$ but approached a value of 16.4 $\mathrm{mg} / \mathrm{L}$ for $1 \mathrm{~h}$ retention time indicating that the second step in the reduction of nitrate the nitrite reduction step is not quantitatively completed because of too short retention time. The results are graphed in (Fig. 5).
Effect of retention time on turbidity values

The following were obtained by treating water in the biological reactor. The Largest turbidity value of 20.4 FTU was found for a retention time of one $h$ and the smallest value of 3.8 FTU for retention time of $48 \mathrm{~h}$ Apparently as the retention time decreases -resulting in a faster rate of water movement through the systemsthe upper layers of the bacterial mass is sloughed off and carried out in the treated water. (Fig. 6).

\section{Temperature variation}

The lowest raw water temperature was measured to be 16 and the highest $18{ }^{\circ} \mathrm{C}$ at well \# 903 . 


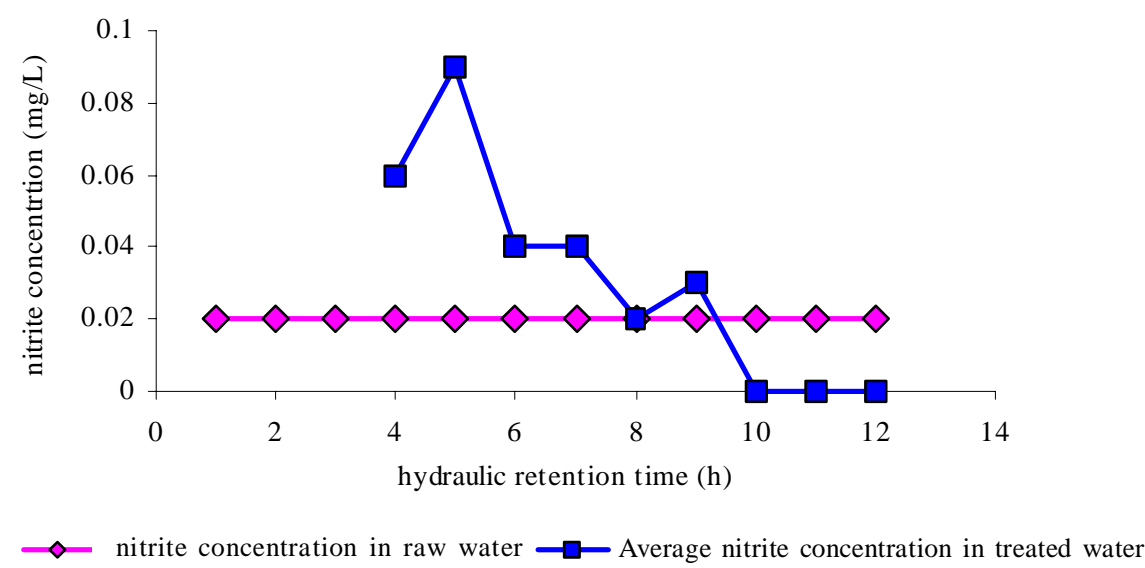

Fig. 5: Variations in concentration of nitrite versus retention time

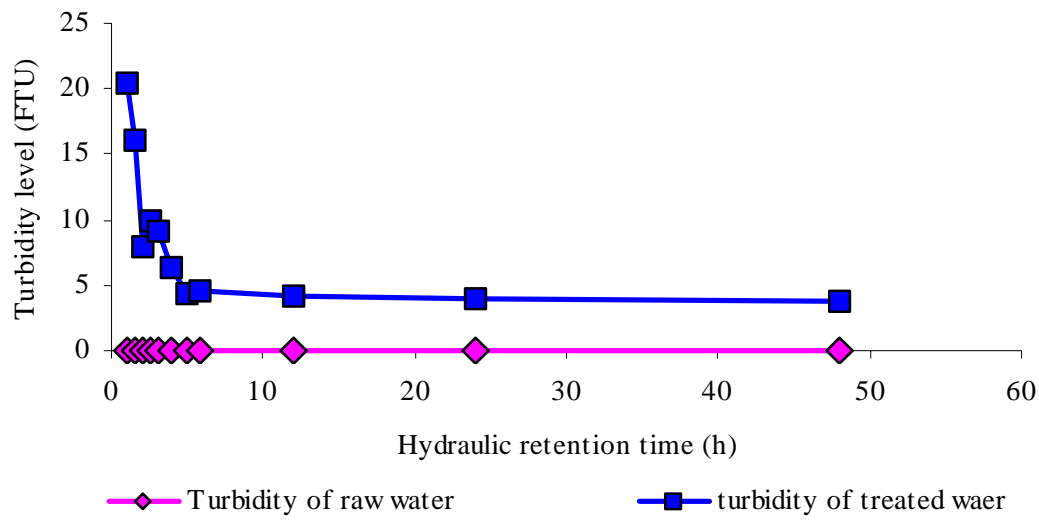

Fig. 6: water turbidity level versus hydraulic retention time

Considering the air temperature effects, the highest value for treated water was measured at $25^{\circ} \mathrm{C}$ during the warmest summer periods and the lowest value at $14{ }^{\circ} \mathrm{C}$ during the winter $\mathrm{h}$ It must be pointed out that a small room equipped with automatic heating system was sued to prevent large variations in operating temperatures. The results were obtained with a maximum-minimum thermometer.

The projects economic analysis (costs)

If a $\mathrm{COD} / \mathrm{N}$ is considered to be equal 2 and a price of $4 \$$ US per liter of acetic acid obtained from the National Petrochemical Co., the cost of biological treatment for each cubic meter of raw water would equal 60 US cents just for the acid. System operations cost such as electricity use of dosing pumps and electromechanical parts as well as labor cost should be added to this amount. It should also be pointed out that the operational costs for a cubic meter of water would be much lower in large scale systems.

\section{DISCUSSION AND CONCLUSION}

The following conclusions were obtained with this research project:

Assuming that the nitrate ion concentration for the raw water is approximately $75 \mathrm{mg} / \mathrm{L}$, the system efficiency would be $77 \%$ for a retention time of $2 \mathrm{~h}$ This efficiency rate may be increased up to $90 \%$.

Based on the evaluations a retention time of two $h$ was selected to be the best because a shorter retention time would decreases the effective reactor volume and results in increased costs. Furthermore, nitrite concentration would increase because of incomplete quantitative reaction in the reactor. Assuming a constant value of 2 for COD/N and a COD=140 mg/L for the raw water, the average value of COD for treated water would be $24 \mathrm{mg} / \mathrm{L}$ given a retention time of $2 \mathrm{~h}$ To remove the remaining COD completely, additional treatment with the use of aeration system or activated charcoal granules would be necessary. Measurements at three exit valves revealed the following: 
- About $80 \%$ of nitrate removal took place up to valve No. 1.

- The results for valves Nos. 1 and 2 (finished valve) were about the same so they were both recorded in the same table.

- Considering the effects of acetic acid, pH should be decreased by one to one and a half units, however, bacterial activities and waste products compensate this lowering of $\mathrm{pH}$.

\section{AKNOWLEDGMENT}

The Authors are grateful to the Research Department, University of Tehran for its financial support.

\section{REFERENCES}

AWWA, (1998). Treatment process selection for particle removal. American Water Works Association, McGraw-Hill.

Bouchard, D. C., Williams, M. K. and Surampalli, R. Y., (1992). Nitrate contamination of groundwater: Sources and potential health effects. J. AWWA., 193-232.

Chapman, D., (1997). Water quality assessments, $2^{\text {ed. }}$ Ed. WHO, UNESCO publications.113-137.

Degremont, G., (1991). Water treatment handbook, Sixth edition, Paris, Firman, France. 1, 201-259.

Hammer, M. J., (1986). Water and wastewater technology. Prentice Hall International Publication. 101-121.
John De Zuane, P. E., (1990). Handbook of drinking water quality standards and control. Second edition, John Wiley Publication, 87-90.

Master, G. M., (1991). Introduction to environmental engineering and science. Prentice Hall International Publication. 56-93.

Mesdaghinia, A. R. and Shariat, M., (1998). Investigation Project on the environmental aspects of industries in Tehran, Phase. I. Department of Environmental Health Engineering, TUMS Publication, 1-2.

Senju, K., Nishi, N., Matsumaru, M. and Minegishi, R.: Waste water treatment efficiency and applications using yeasthydrocarbonic wastewater treatment. Kougai to Taisaku, 25, 1557-1563.

Thanth, N. C. and Simard, R. E., (1973). Biological treatment of wastewater by yeasts. Water Pollution Control Fed, 45, 674-680.

Torabian, A., B. Aminzadeh and M. R. Ghaffarzadeh. (1998). Denitrification of Drinking Wate by Upflow Fixed Bed Reactors Water Waste J., 36, 12-17.

Torabian, A., B. Aminzadeh; S. H. Hashemi. (2002). A Study of nitrate in Tehran ground water and a method of removal, Int. J. Environ. Stud., 57, 725-734.

WHO, (1996). Guidelines for drinking water quality, addendum, $2^{\text {nd. }}$ Edition, World Health Organization, 2, 63-77.

\section{AUTHOR(S) BIOSKETCHES}

Nabi Bidhendi, Gh., Ph.D., is a professor assistant in the Department of Environment, Tehran University, Tehran, Iran. Email: ghhendi@ut.ac.ir

Nasrabadi, T., M.Sc. student in environmental engineering at the University of Tehran. Tehran, Iran.Email: t_nasrabadi@yahoo.com

Sharif Vaghefi, H. R., M.Sc. student in environmental engineering at the University of Tehran.

Hoveidi, H., M.Sc. student in environmental management at the University of Tehran. Tehran, Iran.Email: hoveidi10@yahoo.com

This article should be referenced as follows:

Nabi Bidhendi, Gh., Nasrabadi, T., Sharif Vaghefi, H. R. and Hoveidi, H., (2006). Biological

nitrate removal from water resources, Int. J. Environ. Sci. Tech., 3 (3), 281-287. 